\title{
THE EXTENT OF TRADE LIBERALISATION IN THE 1990S: REVISITED
}

\author{
L. RANGASAMY AND C. HARMSE
}

IN A RECENT ARTICLE IN THIS JOURNAL, Fedderke and Vaze (2001:436-473) undertook an analysis of the extent and effects of trade liberalisation in South Africa during the 1990s. The study (hereafter referred to as the FV study) quantifies the extent of trade (tariff) liberalisation in SA using a measure of the effective protection rate (ERF). Based on their ERP calculations the FV study finds that "more of South Africa's output is protected by tariffs in 1998 than in 1988", and hence deduces from this that, "the much-hyped liberalization of the South African economy has not been fully realized" (Fedderke and Vaze, 2001:447). The purpose of this paper is to ascertain if this is indeed the case and if new evidence exists that gives more complete answers.

The first part of the paper provides a brief overview of some theoretical considerations relating to the measurement of ERP and its use as an indicator of the extent of trade liberalisation. The second part documents the tariff liberalisation undertaken by South Africa during the 1990s. ERP calculations are undertaken in part three and these are compared to those in the FV study. Some conclusions are drawn in the last section. 


\section{SOME THEORETICAL CONSIDERATIONS}

Max Corden $(1966,1969,1971)$ is credited with having formalised the theory of effective protection. However, as Greenaway and Milner (2002:2) note, economists like Taussig, Haberler and Meade, decades earlier signalled the importance of considering tariffs on inputs when analysing protection. The appeal of the ERP measure lies in the fact that it takes into account tariffs imposed on the final product as well as on the intermediate inputs used in the production of that product. In other words, the ERP indicates the total effect on domestic production (value added) of an existing tariff structure (Carbaugh, 2000: 116-117).

With perfect competition, protection (on output and inputs used in the production process) will result in domestic value added diverging from the level prevailing under free trade. The standard measure of the ERP is given by: ${ }^{1}$

$E R P=\frac{V_{t}-V_{f t}}{V_{f t}}$

Where value added under protection is given by $V_{t}$ and value added under free trade by $\mathrm{Vf}_{\mathrm{t}}$. Considering a linear relationship between inputs and outputs with $a_{i j}$ the input-output coefficient for the $i^{i t}$ input used in the production of the $f^{t h}$ output. Considering the nominal tariff level on $j\left(t_{i}\right)$, nominal tariff on input $i\left(\boldsymbol{t}_{i}\right)$ and the share of inputs $i$ in the costs of $\mathrm{j}$ without tariffs $\left(\sum a_{i j}\right)$, the ERP measure is given by:

$E R P=\frac{t_{j}-\sum_{i} a_{i j} t_{i}}{1-\sum_{i} a_{i j}}$

Equation 2 is a common measure used in ERP calculations and is the one used in the FV study. It highlights two important points.

\footnotetext{
${ }^{1}$ See Greenaway (1983) for an elegant review of the concept and an exposition of how it can be measured. Holden (1999) provides a good review of the development of the theory.
} 
Firstly, the overall tariff structure has a tax and subsidy element with the tariff on the output (input) being equivalent to a subsidy (tax) (Greenaway and Milner, 2002). Secondly, effective protection can be negative, that is, an activity can be worse off due to protection on inputs exceeding that on the final product.

The theoretical shortcomings of the ERP concept have been well documented (Jones, 1971; Ethier, 1972, 1977; Bhagwati and Srinivasan, 1973). ${ }^{2}$ More recently Anderson (1998) has also challenged the usefulness of ERP calculations as a measure of protection. In the light of these criticisms it is important to consider the relevance or validity of ERP analysis. In this regard it has been argued that

"even though the theoretical validity of ERP as an indicator of resource pull is somewhat less than was initially asserted or hoped for, it continues to be a nice way to summarise the information on the protection structure resulting from tariffs on inputs and outputs ... if ERPs are used with some care ... even their analytical use can be somewhat suggestive" (Bhagwati and Srinivasan, 1983: 131, quoted in Greenaway, 2002:16).

Thus, ERP measures can help in

"identifying the probabilities or effects on average that may be expected from reforms ... with production falls likely to happen on average in the sectors experiencing declines in effective protection" (Greenaway and Milner, 2002:12).

Given the theoretical shortcomings, the ERP calculations may not necessarily provide the best measure of the likely pull on resources, but in the light of data constraints it may still provide the best description of the overall structure of tariff protection. ${ }^{3}$ Changes in the ERP may therefore provide a useful indicator of

\footnotetext{
2 Some of these shortcomings include the imperfect substitutability between imported and local products, the treatment of non-tradable inputs in the measurement of the ERP, measurement of tariff equivalents of non tariff barriers and the allocation of intermediate inputs to multiple outputs.

Since tariff rates are the only protection measures used in the calculations, the ERP in essence measures tariff protection. ERP measures also provide insights into the phenomenon of tariff escalation.
} 
the extent of tariff liberalisation."'

There are two ways of interpreting the extent of tariff liberalisation from ERP calculations. The first is to consider the difference in ERP measures between two periods; large reductions in the measures will show that the particular sector in question has been subjected to extensive tariff liberalisation. ${ }^{5}$ An alternative is to consider the relative importance of the sectors being subjected to increased tariff liberalisation (increased) protection. Summing the contributions to GDP of all those sectors that have been liberalised (or subjected to increased tariff protection) between any two periods would indicate whether the major part of a country's output has been liberalised or subject to increased protection. This is the approach undertaken in the FV study and is also the one used in this study.

\section{(a) Trade liberalisation during the 1990s}

There is consensus that South African industrialisation was founded on a policy of import substitution. ${ }^{7}$ The path of the import substituting process in South Africa has been contested. Inter alia, McCarthy, 1988, Fallon and Pereira de Silva (1994) and Joffee et al (1995) have argued that South Africa followed the conventional industrialisation process - the industrialisation process began with consumer goods industry and then moved on to "light" industry and finally the establishment of "heavy"

\footnotetext{
4 Holden (2001) has found that there was not a robust relationship between trade policy changes (as depicted by ERP rates) and resource allocation during the 1990s. Given these results, her conclusions are that ERP analysis undertaken for industries independently from the rest of the industries in the economy may not be meaningful.

5 There is however an element of subjectivity involved in deciding the benchmarks for what could be considered large or extensive tariff liberalisation.

6 Since the focus of the study is on tariff reform during the 1990 s only a brief review of protection prior to this period is provided. For a more thorough review see Bell, 1997.

7 see, McCarthy, 1999; Bell, 1993; Strydom, 1995 and Fine and Rustomjee, 1996 for a review and analysis of South Africa's industrialisation path.
} 
industry. On the other hand, Fine and Rustomjee (1996) have contended that South Africa, engaged in the production of "heavy industry" before embarking on the production of consumer goods. There is however less debate on the instruments of trade policy used to support the industrialisation process in SA. Tariffs, quantitative restrictions and export incentives, were the main trade incentives used to drive the industrialisation process. For Belli et al (1993) protection was granted selectively (during some periods to importers rather than on imports) and was premised on the infant industry argument (Fine and Rustomjee, 1996). The selected issues report on South Africa by a staff team of the IMF in 2002, indicates that it was only in 1983 that a first systematic attempt was made to dismantle some of the controls, with around 77 per cent of imports were subject to direct import controls (IMF, March 2000:53).

Export oriented industrialisation began to receive increasing attention in policy circles since the early 1970 s. $^{8}$ The Reynders Commission recommended a diversification of the export base away from a reliance on gold exports. As Bell $(1996,71)$ notes, the commission did not view import liberalisation as a necessary condition for non-gold export production. In 1972, a tax allowance for export marketing expenses was one of the first direct export incentives introduced by the government. A new system of export incentives then followed in September 1980. By the beginning of the 1990s the official policy stance was one of export-oriented industrialisation. The General Export Incentive Scheme (GEIS) was introduced on 1 April 1990, with the objective of encouraging the production of value added exports. However, while export subsidies were used to reduce the anti export bias in the economy, the view that the path to export production should entail trade (and more specifically tariff) liberalisation began to gain ground. This is evident in the recommendations made by an official investigation into South Africa's tariff protection policy:

${ }^{8}$ see Bell, 1993, 1996 and Tips, 2002 for a review of the protective measures during 1970 to 2000. 
"Progress to greater export orientation, requires the responsible adjustment of the competitiveness of the existing industrial structure, which has been built up through import replacement, so as to enable it to deliver products at prices more in line with world prices. A generally accepted method of achieving this is to reduce tariffs and in addition, to follow a realistic exchange rate policy. The reduction of import tariffs is therefore an integral part of a process of progress towards export orientation" (IDC, 1990: p i-ii). ${ }^{9}$

This view was based on the evidence that South Africa: "had the most tariff lines (more than 13000), most tariff rates (200 ad valorem rates), the widest range of tariffs and the second highest level of dispersion (as measured by the coefficient of variation) among developing countries" (IMF, March 2000:54).

It was further argued that: "the lowering of tariffs will, however, serve first and foremost to strengthen the export orientation of South Africa's trade policy" (IDC, 1990:v). There was thus a firm belief that the tariff protection policies (of the previous decades) created an anti export bias and hence did not promote competitiveness and economic growth.

At the beginning of 1990, the protection system consisted of quantitative restrictions, customs duties and import surcharges. In addition the protection policy was subject to frequent changes, biased against exports and fairly complex (Fallon and Pereira de Silva (1994:81). ${ }^{10}$ Table 1 captures the tariff protection prevailing at the beginning of the 1990s. ${ }^{11}$ The overall statutory tariff while not too high (approximately 28 per cent) by international standards, nevertheless had a wide dispersion. Within the manufacturing sector, consumer goods enjoyed the highest protection.

With the election of a democratic government in 1994, the

9 The minister of trade, industry and tourism commissioned the Industrial Development Corporation, in collaboration with the Board of Trade and Industry, to "investigate the efficacy of the existing tariff protection policy".

10 The complexity was due to the variety of different tariff rates and exemptions granted on a firm-by-firm level rather than a product-by- product basis.

II The calculations were based on the 1989, 1990 and 1991 tariff schedules. In addition ad valonm equivalent rates were calculated for formula duties and other specific duties. 
economic policy bias towards exports as a major stimulant of economic growth was further entrenched. This is clearly borne out in the Growth, Employment and Redistribution (GEAR) strategy, which has since become a cornerstone of government policy. According to GEAR:

"sustained growth on a higher plane requires a transformation towards a competitive outward-oriented economy" (Gear, 1996: 3). The challenge for economic policy was to create: "a competitive platform for a powerful expansion by the tradable goods sector" which is taken to mean, "accelerated growth of non-gold exports" (Gear, 1996:3).

Gear is aimed at: "strengthening the competitive capacity of the economy in the long term" (Gear, 1996:7). Further; competitiveness in the tradable goods sector was to be achieved through: "a reduction in tariffs to contain input prices" (Gear, 1996:4). ${ }^{12}$

Table 1. Nominal Protection at the beginning of the 1990 s

\begin{tabular}{llllll}
\hline & $\begin{array}{l}\text { Weighted } \\
\text { mean }\end{array}$ & $\begin{array}{l}\text { Unweighted } \\
\text { mean }\end{array}$ & $\begin{array}{l}\text { Minimum } \\
\text { rate }\end{array}$ & $\begin{array}{l}\text { Maximum } \\
\text { rate }\end{array}$ & $\begin{array}{l}\text { Coefficient of } \\
\text { variation }\end{array}$ \\
Whole economy & 28 & 29 & 0 & 1389 & 159.8 \\
Agriculture & 23 & 16 & 0 & 147 & 144.9 \\
Mining & 3 & 3 & 0 & 20 & 186.6 \\
Manufacturing & 28 & 30 & 0 & 1389 & 158.4 \\
Consumer goods & 60 & 48 & 0 & 1389 & 125.5 \\
Intermediate goods & 17 & 18 & 0 & 1320 & 198.9 \\
Capital goods & 19 & 17 & 0 & 135 & 103.5 \\
\hline
\end{tabular}

Source: Fallon, P. and de Silva, L.A. 1994: "South Africa: Economic Performance and

Policies", Informal discussion papers, World Bank, Washington. P.83

It is quite apparent from the above that government policy is premised on the assumption that exports are vital for economic growth. Reduced input costs improve cost competitiveness, which in turn facilitates increased export production.

By the mid 1990s it was clearly evident that the government was committed towards abolishing GEIS partly as a result of its incompatibility with GATT rules and partly because of a policy shift that entailed tariff liberalisation as a means of reducing the

${ }^{12}$ It is interesting to note that the objective of striving for international competitiveness is not meant to be isolated from social objectives. In fact one of the stated intentions of economic policy is "to support a competitive and more labourintensive growth path" (GEAR, 1996, p 7). 
anti export bias in the economy.

The governments tariff liberalisation policy culminated in South Africa's offer to the GATT in 1994 and implemented in January 1995. In terms of the GATT offer, South Africa agreed to bind 98 per cent of all tariff lines and to cut tariffs by a third (Holden, 2001). The country also offered to convert all quantitative restrictions on agricultural imports to bound ad valorem rates and to liberalise the sensitive industries over an eight-year period (IMF, 2000:54). The offer to GATT clearly displayed a commitment to the opening up the economy to foreign competition. ${ }^{13}$ In terms of the offer, industrial protection was to be substantially reduced over a five-year period from an average tariff of around 12 per cent in 1994 to approximately 5 per cent in 2001. The average import weighted tariff rates were to be reduced to well within the WTO bound rates; from 34 per cent to 17 per cent for consumption goods, 8 per cent to 4 per cent for intermediate goods and 11 per cent to 5 per cent for capital goods (TIPS, 2002, p.ll). ${ }^{14}$

South Africa's commitment to her liberalisation offer is borne out by an analysis of the applied rate over the latter half of the 1990s (see Table 2). The average import weighted tariffs since the GATT offer, had been significantly reduced from 28 per cent in 1990 to 10 per cent in 1998 (IMF, 2000:55). For agricultural products the rate has been lowered from 9.23 per cent (1996) to 1.4 per cent (2000) while for industrial products it was reduced from 11.4 (1996) per cent to 8.6 per cent (2000). The average for the economy as a whole has seen applied rates come down from 11.3 per cent in 1996 to 7.3 per cent in 2000 (TIPS, 2002:14). These statistics on output protection confirm that South Africa has made significant strides down the tariff liberalisation path. However, can the same be said of the "overall" tariff structure? In order to answer this question we need to analyse tariff changes on both inputs and outputs.

\footnotetext{
13 This section is mainly based on TIPS (2002).

The bound rates are 26 per cent, 4 per cent and 15 per cent for consumption, intermediate and capital goods respectively.
} 
Table 2. South Africa: Trade Regime, 1990 and 1998

(In per cent, unless otherwise indicated)

\begin{tabular}{|c|c|c|}
\hline Tariffs & 1990 & 1998 \\
\hline \multicolumn{3}{|l|}{ Manufacturing } \\
\hline Maximum tariff & 1389 & 72 \\
\hline Average import-weighted tariff & 28 & 10 \\
\hline Average unweighted tariff & 30 & 14 \\
\hline Number of tariff bands & $>200$ & 72 \\
\hline Standard deviation & 43 & 15 \\
\hline Number of tariff lines 1 / & $>13000$ & 7814 \\
\hline Per cent of tariff lines with non ad valorem duties $1 /$ & 28 & 26 \\
\hline Range of effective protection $2 /$ & 189 to -411 & 204 to -2 \\
\hline Average import-weighted surcharge 3/ & 6 & 0 \\
\hline Import surcharge bands & 10,15 , and 40 & eliminated \\
\hline \multicolumn{3}{|l|}{ Agriculture } \\
\hline Average tariff & 25 & 2.2 \\
\hline Average import surchange & 8 & 0 \\
\hline Export subsidy 4/ & 17 & eliminated \\
\hline \multicolumn{3}{|l|}{ Export taxes } \\
\hline Diamonds & 15 & 15 \\
\hline Quantitative restrictions on imports 5/ of which: & 15 & virtually eliminmated \\
\hline Agriculture & 74 & virtually eliminmated \\
\hline Manufacturing & 14 & virtually eliminmated \\
\hline \multirow[t]{2}{*}{ Quantitative restrictions on exports; goods 3/ } & diamonds & Diamonds \\
\hline & \multicolumn{2}{|l|}{21 agric comm. } \\
\hline \multicolumn{3}{|l|}{ Memorandum items: } \\
\hline Trade tax revenue as share of total revenue & 7.9 & 4.0 \\
\hline Import taxes as share of imports & 10.8 & 4.1 \\
\hline Export subsidies as a share of GDP & 0.3 & 0.0 \\
\hline \multicolumn{3}{|c|}{$\begin{array}{l}\text { Source: IMF (2000). South Africa:selested issues, March 2000, IMF Staff Country Report } \\
\text { no.00/42 p55. }\end{array}$} \\
\hline \multicolumn{3}{|l|}{ 1/ The figure for 1998 refers to June 1997.} \\
\hline \multicolumn{3}{|c|}{ 2/ At ISIC three-digit level; excludes import surcharge. } \\
\hline \multicolumn{3}{|l|}{ 3/ The figure for 1990 refers to 1992 . } \\
\hline \multicolumn{3}{|c|}{ 4/ Actual subsidy disbursements were 2.7 per cent of exports in $1990 / 91$} \\
\hline \multicolumn{3}{|c|}{$\begin{array}{l}\text { 5/ The figure for } 1990 \text { refers to } 1992 \text {. As per cent of total tariff lines (other than those } \\
\text { mainted for health, security, and environmental reasons). }\end{array}$} \\
\hline
\end{tabular}

\section{TRADE (TARIFF) LIBERALISATION AND THE ERP}

Effective protection captures the net protection accorded to an industry by taking into account the protection imposed on both output and intermediate inputs used in the production process. Various studies have used ERP analysis to appraise SA's protection policy during the 1990s (IDC, 1996; Fedderke and Vaze, 2001; TIPS, 
2002). The FV study has recently explicitly questioned the extent of tariff liberalisation in the 1990 s. ${ }^{15}$ The study claims that: "more of South Africa's output is protected by tariffs in 1998 than in 1988" and hence concludes that: "the much-hyped liberalisation of the South African economy in the 1990's has not been fully realised" (Fedderke and Vaze, 2001:447). Using a similar methodology, this paper will appraise this result of the FV study.

The FV study analyses the protection accorded to 38 economic sectors. Average EPRs (based on tariff duties collected) were calculated for the period 1988-93 and 1994-98. Sectors were classified as more protected $(\mathrm{P})$ if the EPR increased by more than 1 per cent, liberalised (L) if it decreased by more than 1 per cent and moderately protected (M) otherwise. In terms of these criteria 8 sectors were classified as more protected, 16 as moderately protected and 14 as liberalised. The FV study claims that the 8 protected sectors accounted for more that 50 per cent of the GDP in 1998.

A defining characteristic of this study relates to the use of collected customs duties to estimate the tariff rates rather than the use of statutory tariff rates in the calculations of ERPs. There are a couple of points that can be made in this regard. The first relates to high or prohibitive tariff rates not being reflected in the customs revenues collected. Secondly, it is important to recognise that in the case of SA, imports are recorded when they land in the country while import duties are only paid when goods leave the warehouses at the port. Thus, it is possible that in some cases importers only pay the customs duties after the year in which the imports were reflected in customs records. In these cases tariff calculations based on revenue collections will understate the "actual" tariff rates applicable to the products. It is unclear to what extent this issue has been addressed in the FV study. ${ }^{16}$

\footnotetext{
15 The study also establishes a positive relationship between tariff liberalisation and export production. The results pertaining to this aspect are not analysed in this paper.

16 This is not to state that statutory rates are superior. In fact the issue of
} 
Table 3. Tariff phase-down under the WTO

\begin{tabular}{|c|c|c|c|c|c|c|c|c|c|c|c|c|}
\hline New & & 1994 & 1995 & 1996 & 1997 & 1998 & 1999 & 2000 & 2001 & 2002 & 2003 & 2004 \\
\hline $\begin{array}{r}\text { ISIC } \\
3\end{array}$ & Textiles & 30.1 & 33.8 & 31.8 & 24.9 & 23.4 & 21.9 & 20.3 & 18.7 & 17.3 & 17.3 & 17.3 \\
\hline 4 & Clothing & 73.7 & 73.6 & 68.2 & 54.6 & 50.5 & 46.4 & 42.4 & 37.7 & 33.2 & 33.2 & 33.2 \\
\hline 5 & $\begin{array}{l}\text { Leather\& } \\
\text { leather produc }\end{array}$ & 14.9 & 14.8 & 14.1 & 16.5 & 15.7 & 14.8 & 14.8 & 14.8 & 14.8 & 14.8 & 14.8 \\
\hline 6 & Footwear & 37.5 & 41.6 & 39.1 & 36.8 & 34.2 & 29.1 & 29.1 & 29.1 & 29.1 & 29.1 & 29.1 \\
\hline 7 & $\begin{array}{l}\text { Wood \& wood } \\
\text { production }\end{array}$ & 13.9 & 3.6 & 3.4 & 3.5 & 3.3 & 3.1 & 3.1 & 3.1 & 3.1 & 3.1 & 3.1 \\
\hline 8 & $\begin{array}{l}\text { Paper\& paper } \\
\text { production }\end{array}$ & 9.6 & 9.3 & 9.1 & 8.8 & 8.7 & 8.5 & 7.9 & 7.3 & 6.8 & 6.2 & 5.6 \\
\hline 9 & $\begin{array}{l}\text { Printing \& } \\
\text { publishing }\end{array}$ & 8.1 & 1.3 & 1.2 & 1.1 & 1.0 & 1.0 & 1.0 & 1.0 & 1.0 & 1.0 & 1.0 \\
\hline 10 & $\begin{array}{l}\text { Petroleum \& } \\
\text { petrol product }\end{array}$ & 1.6 & - & - & - & - & - & - & - & - & - & - \\
\hline 11 & $\begin{array}{l}\text { Industrial } \\
\text { chemicals }\end{array}$ & 9.3 & 7.5 & 7.5 & 1.7 & 1.7 & 1.6 & 1.6 & 1.6 & 1.6 & 1.6 & 1.6 \\
\hline 12 & $\begin{array}{l}\text { Other } \\
\text { Chemical prod }\end{array}$ & 9.0 & 3.8 & 3.7 & 2.7 & 2.6 & 2.5 & 2.5 & 2.5 & 2.5 & 2.5 & 2.5 \\
\hline 13 & $\begin{array}{l}\text { Rubber } \\
\text { products }\end{array}$ & 30.5 & 14.5 & 14.1 & 15.8 & 15.4 & 14.9 & 14.6 & 14.4 & 14.0 & 14.0 & 14.0 \\
\hline 14 & $\begin{array}{l}\text { Plastic } \\
\text { products }\end{array}$ & 19.8 & 14.7 & 13.7 & 13.2 & 12.6 & 12.0 & 12.0 & 12.0 & 12.0 & 12.0 & 12.0 \\
\hline 15 & $\begin{array}{l}\text { Glass \&glass } \\
\text { production }\end{array}$ & 11.8 & 9.5 & 9.0 & 8.3 & 7.9 & 7.6 & 7.6 & 7.6 & 7.6 & 7.6 & 7.6 \\
\hline 16 & $\begin{array}{l}\text { Non-metallic } \\
\text { Mineral produc }\end{array}$ & 10.6 & 8.7 & 8.1 & 8.4 & 8.0 & 7.7 & 7.7 & 7.7 & 7.7 & 7.7 & 7.7 \\
\hline 17 & $\begin{array}{l}\text { Basic iron \& } \\
\text { steel products }\end{array}$ & 7.6 & 4.4 & 4.2 & 4.2 & 4.1 & 3.9 & 3.9 & 3.9 & 3.9 & 3.9 & 3.9 \\
\hline 18 & $\begin{array}{l}\text { Non-ferrous } \\
\text { Metal produc }\end{array}$ & 2.3 & 2.3 & 2.3 & 2.3 & 2.2 & 2.0 & 2.0 & 2.0 & 1.9 & 1.7 & 1.7 \\
\hline 19 & $\begin{array}{l}\text { Metal product, } \\
\text { excl machinery }\end{array}$ & 13.1 & 8.2 & 7.8 & 7.8 & 7.6 & 7.4 & 7.4 & 7.4 & 7.4 & 7,4 & 7.4 \\
\hline 20 & $\begin{array}{l}\text { Non-electrical } \\
\text { Machinery }\end{array}$ & 6.5 & 1.4 & 1.3 & 1.4 & 1.3 & 1.3 & 1.3 & 1.3 & 1.3 & 1.3 & 1.3 \\
\hline 21 & $\begin{array}{l}\text { Electrical } \\
\text { machinery }\end{array}$ & 11.0 & 6.1 & 6.0 & 5.8 & 5.8 & 5.7 & 5.7 & 5.7 & 5.7 & 5.7 & 5.7 \\
\hline 22 & $\begin{array}{l}\text { Radio, } \\
\text { Television \& } \\
\text { communic }\end{array}$ & 12.1 & 5.1 & 3.7 & 2.4 & 2.3 & 2.3 & 2.3 & 2.3 & 2.3 & 2.3 & 2.3 \\
\hline 23 & $\begin{array}{l}\text { Professional } \\
\text { Equipment }\end{array}$ & 7.2 & 0.2 & 0.2 & 0.3 & 0.3 & 0.3 & 0.3 & 0.3 & 0.3 & 0.3 & 0.3 \\
\hline 24 & $\begin{array}{l}\text { Motor vehicles, } \\
\text { parts \& } \\
\text { accessories }\end{array}$ & 55.4 & 33.5 & 31.7 & 29.3 & 27.9 & 26.1 & 24.8 & 23.2 & 22.1 & 22.1 & 22.1 \\
\hline 25 & $\begin{array}{l}\text { Other } \\
\text { Transp.equip }\end{array}$ & 1.4 & 0.4 & 0.4 & 0.3 & 0.3 & 0.2 & 0.2 & 0.2 & 0.2 & 0.2 & 0.2 \\
\hline 26 & Fumiture & 28.1 & 21.4 & 20.8 & 20.2 & 19.6 & 18.9 & 18.9 & 18.9 & 18.9 & 18.9 & 18.9 \\
\hline 27 & $\begin{array}{l}\text { Other } \\
\text { manufacturing }\end{array}$ & 2.9 & 1.0 & 1.0 & 5.2 & 5.1 & 5.0 & 4.9 & 4.9 & 4.9 & 4.9 & 4.9 \\
\hline 82 & Mining & 2.7 & 0.6 & 0.6 & 0.5 & 0.4 & 0.4 & 0.4 & 0.4 & 0.4 & 0.4 & 0.4 \\
\hline Total & & 11.7 & 7.2 & 6.8 & 6.1 & 5.8 & 5.5 & 5.3 & 5.1 & 4.9 & 4.9 & 4.9 \\
\hline
\end{tabular}

Source: $\quad$ IDC quoted in Trade and Industry Policy Strategy (TIPS), 2002: The state of trade policy in South Africa, Johannesburg.

whether statutory rates (rather than collected rates) are more appropriate is debatable. For example, statutory rates do not reflect rebates and does not capture the effects of smuggling. 
Table 4 captures the ERP calculations of the 38 sectors considered in the FV study. These are reflected in rows 1 to 38, while rows 39 to 46 reflect the sectors that are not considered in the study. ${ }^{17}$ In addition, the contributions to value added are captured for all the sectors for the years 1988, 1998 and 2001 under columns 2 to 4. The ERP calculations (averages for period 1988-93 and 1994-98) are reflected in columns 5 and 6 . Some derivations from the ERP calculations and trade policy classifications are depicted in columns 7 to 10 .

Since the FV study considers only 38 sectors it is important to ascertain the relative importance of these sectors in the economy. The 38 sectors considered in the FV paper made up 72 per cent (62 per cent) of total GDP in 1988 (1998). ${ }^{18}$ Thus, the point to bear in mind is that the relative importance of the 38 sectors has decreased over the period. Thus, the conclusions in the FV study are based on an analysis of only around two thirds of the South African economy. The question therefore is whether the results of the FV study still hold if the analysis (calculations) is (are) done with reference to the whole economy?

As pointed out above, FV classify the sectors on the basis of the change in the average ERP between the two periods (1988-93 and 1994-98). The calculations and classifications are reflected in columns 7 and 9 respectively. As per the FV study, column 9 depicts the 14 sectors that were liberalised (L), 16 sectors that were moderately (M) protected and 8 sectors that enjoyed increased levels of protection $(\mathrm{P})$ between the two periods. The relative importance of the sectors to the GDP of the 38 sectors considered in the FV study and the overall economy are reflected under column 9 (rows 47 to 52). ${ }^{19}$ As an illustration we expound on

17 These are mainly non-tradable sectors.

18 These calculations are captured in rows 50 to 52; an explanation on how to interpret these representations is provided later on in this section. By 2001 these sectors made up 61 per cent.

19 The relative importance is for the years 1988, 1998 and 2001. 
column 9, row 49. The 14 liberalised sectors made up 23 per cent (in 1988 and 1998) and 22 per cent (in 2001) of the GDP of the 38 sectors considered in the FV study. This contribution is higher than that recorded in the FV study. ${ }^{20}$ However, in terms of the overall significance of the tariff liberalisation, column 9 (row 50), indicates that these 14 sectors contribution to the total GDP of South Africa decreased from 16 per cent (1988) to 14 per cent (13 per cent) in 1998 (2001). Similarly, the 16 moderately protected sectors contribution to the GDP of the 38 sectors increased from 43 per cent (1988) to 46 (1998) to 45 per cent (2001) while the contribution to the overall economy decreased from 30 per cent (1988) to 29 per cent (1998) to 28 per cent (2001). ${ }^{21}$ The sectors enjoying more protection decreased their contribution to the GDP of 38 sectors from 34 per cent in 1988 to 30 per cent in 1998 before increasing to 33 per cent in 2001. These sectors contribution to the economy decreased from 25 per cent in 1988 to 19 per cent (20 per cent) in 1998 (2001). These results refute the claim made in the FV study that: "more of South Africa's output is protected by tariffs in 1998 than in 1988" (Fedderke and Vaze, 2001:447). By 2001, liberalised (protected) sectors accounted for 13 per cent (20 per cent) of total GDP in 2001. So whereas the percentage of output enjoying tariff protection was higher than that subject to tariff liberalisation, the protected sectors did not make up the major proportion of the country's GDP.

An important factor influencing the results and conclusions reached in the FV study relate to the classification of the extent of liberalisation The calculations as undertaken by FV for the classification of the sectors as liberalised $(\mathrm{L})$, moderately protected $(\mathrm{M})$ or protected $(\mathrm{P})$ do not capture the relative significance of the change in the ERP. For example, from Table 4 the 0.6 per cent reduction in the ERP between the two periods represents a 4 per

\footnotetext{
20 The FV study records that the liberalised sectors account for just over $15 \%$ of the total GDP from the 38 sectors.

21 Classified as $\mathrm{M}$ in the Table.
} 
cent and 76 per cent decrease in the ERP for the rubber (row 17) and other transport sectors (row 16) respectively. Column 8 captures the percentage change in the ERP measures between the two periods (1988-93 and 1994-98) $P$ All sectors that experienced a reduction (increase) of at least 10 per cent in their ERP measures are classified as liberalised (protected) and moderately protected otherwise (classification reflected under column 10) $P$ In terms of this classification 21 sectors are classified as liberalised, 11 sectors as moderately protected and 6 sectors as protected. In terms of the contribution to total value added, the protected sectors made up 12 per cent of total GDP in 1988 as compared to 9 per cent (8 per cent) in 1998 (2001). ${ }^{24}$ Stated differently, it is apparent that less of South Africa's output enjoyed tariff protection in 2001 (or even in 1998) than in 1988.

In terms of both the classifications used, it is apparent that the protected (liberalised) sectors made up approximately 8-20 per cent (between 13-19 per cent) of total GDP in 2001 as compared to between $12-25$ per cent (16-21 per cent). ${ }^{25}$ Thus, contrary to what is claimed in the FV study, it is apparent that more of South Africa's output is not protected by tariffs in 1998 (or even in 2001) as compared to 1988.

However, it should be remembered that the tariff calculations used thus far were based on collected rather than on statutory rates. Thus, the question is whether the situation changes when one considers statutory rates? In order to ascertain if this is indeed the case, we consider ERP calculations based on statutory rates as undertaken by the IDC (1996).

Table 5 (in annex) reflects the ERP calculations for 1993 and 1999 undertaken by the IDC on the basis of statutory tariff rates. Our aim is to see if the analysis portrayed above is corroborated

\footnotetext{
22 This captures the relative rather than the absolute change in the ERP.

23 It is acknowledged that the $10 \%$ dividing line is arbitrary and as such is only suggestive.

24 See row 52, column 10 in table 4 in annex.

25 In 1998 protected (liberalised) sectors contributed between amounted to 9-19 per cent (14-18 per cent) to total GDP.
} 
by these calculations. Due to data constraints we are not able to undertake a comparison across all the sectors included in the IDC study. ${ }^{26}$ However, there are sufficient data points to provide at least an indication of the extent of trade liberalisation. The Table reflects the same two classifications used above to capture the trade policy stance during 1993 and 1999. Considering the relative percentage change in ERP between 1993 and 1999 we observe that the liberalised (protected) sectors contribution to the sales of the 51 manufacturing industries decreased from 67 per cent (11 per cent) to 66 per cent (10 per cent). ${ }^{27}$ Similarly the contribution to total sales of the manufacturing sector has decreased from 50 per cent (8 per cent) to 49 per cent (8 per cent) for the liberalised (protected) industries during 1993 and 1999. Similarly, by considering the absolute change between 1993 and 1999, we see that the protected sectors made up around 10 per cent of total manufacturing sales, whilst liberalised sectors contribute approximately 61 per cent of total sales during the period under analysis. ${ }^{28}$ These results suggest that by the end of the $1990 \mathrm{~s}$ more of South Africa's manufacturing output was liberalised than protected.

There is an additional issue relating to the tarrification of the agricultural sector that warrants mention given the influence it could exert on the calculations undertaken in both FV study and in

26 Our main constraints relate to the industry classifications used in the IDC study. The industry classification in the IDC study is at the SIC version 3 level while sectoral data is currently available on at SIC version 5 level. A link provided by the TIPS was used to link 51 SIC version 3 manufacturing sectors (of the 71 sectors considered in the IDC studies) with their corresponding sales data. Hence the point to bear in mind is that while we are not considering all the sectors, the results are nevertheless indicative of the extent of liberalisation undertaken during the 1990s. Sales data was used as a proxy for contribution to GDP due to the unavailability of GDP data on an SIC (version 5) 4 digit level.

27 The calculations and classifications are represented in columns 9 and 11 respectively.

28 The classification used here is similar to the one used in the previous table. A one per cent reduction classifies the sector as liberalised, a one per cent increase as protected and moderately protected otherwise. 
this paper. As part of the WTO commitment, quantitative restrictions were converted into ad-valorem rates during the 1990s (TIPS, 2002). This has a direct effect on the tariffs collected and could lead to increases in duties collected. This being the case, you could have the case of the agricultural sector's protection being overstated and those of the other industries using agricultural inputs being understated. This problem exists also if statutory rates are used in the calculation of the ERP. However, in terms of our calculations the agricultural sector is classified as enjoying more protection during the 1990s and as such biases the total output under protection upwards. If the tarrification of the agricultural sector does not represent an increase in the protection to this sector, the output of the agricultural sector would not form part of the total output under protection. This would lend further support to our argument. On the other hand, if agriculture's protection is overstated then the protection of the other industries using agricultural inputs is understated and this could influence the strength of our argument. However, the information on the tariff revenues collected on agricultural products would seem to suggest that the tarrification measures did not lead to a significant increase in protection for the agricultural sector. The tariff rate for agriculture increased marginally from 1.4 per cent in 1993 to 1.7 per cent in 1994 before decreasing again to 1.4 per cent in $1995 .^{29}$

\section{CONCLUSION}

During the 1990s there was a deliberate attempt on the part of the South African authorities to increase the pace of tariff liberalisation. The WTO offer in 1994 and the subsequent liberalisation - in some cases at faster rates than the WTO commitments - has meant that the tariff protection, which

\footnotetext{
${ }^{29}$ The tariffs collected on products within the SIC 1 category was used in the calculation for the tariff rates. This information was obtained from the DTI. The results are even more pronounced if one considers statutory rates. According to IMF (2000) the statutory average rates decreased from 25 per cent in 2000 to 2.2 per cent in 1998 (see Annex 2).
} 
sheltered domestic industry from international competition in the past, has largely diminished. This view is support by an analysis of ERP calculations during the 1990s. Whether liberalisation should have gone further and faster during the 1990s is a legitimate question with the answer to this question depending on a critical analysis of the liberalisation programme during the 1990s. However, to argue that more of South Africa's output has been subjected to increased levels of protection during the 1990s is not only incorrect but is also a misrepresentation of facts. 
APPENDIX

Table 4. Extent of Trade liberalisation in $S A$ (ERP calculation based on collected tariff revenues)

\begin{tabular}{|c|c|c|c|c|c|c|c|c|c|}
\hline \multirow[t]{2}{*}{ Sector } & \multicolumn{3}{|c|}{ Contribution to value added $\mathrm{Rm}$} & \multirow{2}{*}{$\begin{array}{l}\text { Average ERP for } \\
1988-93\end{array}$} & \multirow{2}{*}{$\begin{array}{l}\text { Average } \\
\text { ERP for } \\
\text { 1994-98 }\end{array}$} & \multirow{2}{*}{$\begin{array}{l}\text { Change in EPR } \\
\text { (FV class) }^{1}\end{array}$} & \multirow{2}{*}{$\begin{array}{l}\text { \% change in } \\
\text { EPR }^{2}\end{array}$} & \multirow{2}{*}{$\begin{array}{l}\text { Liberali } \\
\text { sation stance } \\
\text { (EPR 88-93 minus } \\
\text { 94-98) (FV class) }\end{array}$} & \multirow{2}{*}{$\begin{array}{l}\text { Liberali } \\
\text { sation } \\
\text { (\% change in } \\
\text { EPR) }\end{array}$} \\
\hline & 1988 & 1998 & 2001 & & & & & & \\
\hline [1] & {$[2]$} & [3] & {$[4]$} & {$[5]$} & {$[6]$} & {$[7]=[6]-[5]$} & {$[8]=[7] /[5] * 100$} & [9] & {$[10]$} \\
\hline 1 Paper and Paper products & 1655 & 5571 & 7462 & 1.145 & 0.616 & -0.529 & -46 & L & L \\
\hline 2 Glass and glass products & 351 & 1020 & 1313 & 0.987 & 0.564 & -0.423 & -43 & I & L \\
\hline 3 TV radio and equipment & 884 & 2337 & 3050 & 0.115 & 0.046 & -0.069 & -60 & L & L \\
\hline 4 Plastic products & 1062 & 4146 & 6953 & 0.187 & 0.118 & -0.069 & -37 & L & L \\
\hline 5 Footwear & 462 & 719 & 578 & 0.300 & 0.244 & -0.056 & -19 & L & L \\
\hline 6 Furniture & 1105 & 3011 & 3196 & 0.092 & 0.038 & -0.054 & -59 & L & L \\
\hline 7 Basic Iron and Steel & 3094 & 9590 & 10612 & 0.210 & 0.164 & -0.046 & -22 & L & L \\
\hline 8 Motor vehicles Parts & 3074 & 8387 & 12670 & 0.063 & 0.032 & -0.031 & -49 & L & L \\
\hline 9 Wearing apparel & 1315 & 4305 & 4508 & 0.115 & 0.084 & -0.031 & -27 & L & L \\
\hline 10 Other manufactures & 1351 & 6267 & 6419 & 0.045 & 0.014 & -0.031 & -69 & L & L \\
\hline 11 Basic Chemicals & 1809 & 6384 & 8186 & 0.058 & 0.028 & -0.030 & -52 & L & L \\
\hline 12 Basic non ferrous metals & 1268 & 4740 & 6374 & 0.063 & 0.044 & -0.019 & -31 & L & L \\
\hline 13 Professional and scientific products & 289 & 508 & 679 & 0.098 & 0.084 & -0.014 & -15 & L & L \\
\hline 14 Electrical machinery & 3210 & 6754 & 8768 & 0.042 & 0.030 & -0.012 & -28 & L & L \\
\hline 15 Electrical, Gas and Steam & 7081 & 19249 & 20658 & 0.070 & 0.062 & -0.008 & -11 & L & L \\
\hline 16 Other transport & 832 & 1034 & 1440 & 0.008 & 0.002 & -0.006 & -76 & L & L \\
\hline 17 Rubber & 602 & 1356 & 1930 & 0.170 & 0.164 & -0.006 & -4 & I & $\mathrm{M}$ \\
\hline 18 Other chemicals \& Manmade fibres & 2525 & 10269 & 13975 & 0.040 & 0.034 & -0.006 & -15 & L & L \\
\hline 19 Wood and wood production & 765 & 2831 & 3337 & 0.018 & 0.014 & -0.004 & -24 & L & L \\
\hline 20 Building Construction & 4836 & 14126 & 15947 & -0.007 & -0.008 & -0.001 & 20 & $\mathrm{M}$ & P \\
\hline 21 Non metallic minerals & 1510 & 3775 & 4660 & 0.008 & 0.008 & 0.000 & -4 & $\mathrm{M}$ & $\mathrm{M}$ \\
\hline $\begin{array}{l}22 \text { Med, dental, health and veterinary } \\
\text { services }\end{array}$ & 1781 & 12027 & 16180 & 0.000 & 0.000 & 0.000 & 0 & $\mathrm{M}$ & $\mathrm{M}$ \\
\hline 23 Metal prod excluding machinery & 3031 & 8124 & 10028 & 0.010 & 0.010 & 0.000 & 0 & $\mathrm{M}$ & $\mathrm{M}$ \\
\hline 24 Coal Mining & 3287 & 9532 & 13797 & -0.010 & -0.010 & 0.000 & 0 & $\mathrm{M}$ & M \\
\hline 25 Transport and Storage & 14625 & 43850 & 53283 & 0.000 & 0.000 & 0.000 & 0 & $\mathrm{M}$ & $\mathrm{M}$ \\
\hline
\end{tabular}




\begin{tabular}{|c|c|c|c|c|c|c|c|c|c|c|}
\hline & Wholesale and Retail Trade & 22910 & 83206 & 108684 & 0.000 & 0.000 & 0.000 & 0 & $\mathrm{M}$ & $\mathrm{M}$ \\
\hline 27 & Coke and refinery petrol & 2471 & 5531 & 6631 & -0.013 & -0.012 & 0.001 & -10 & $\mathrm{M}$ & L \\
\hline 28 & Machinery \& Equipment & 2479 & 6311 & 7875 & -0.002 & 0.000 & 0.002 & -100 & $\mathrm{M}$ & L \\
\hline 29 & Beverages & 1912 & 7611 & 9684 & 0.008 & 0.012 & 0.004 & 44 & $\mathrm{M}$ & P \\
\hline 30 & Frinting, publishing and recording & 1277 & 4372 & 6191 & 0.130 & 0.134 & 0.004 & 3 & $\mathrm{M}$ & $\mathrm{M}$ \\
\hline 31 & Other Mining & 5229 & 17846 & 35019 & -0.062 & -0.054 & 0.008 & -12 & P & $\mathrm{L}$ \\
\hline 32 & Finance and Insurance & 12080 & 51943 & 79988 & -0.195 & -0.184 & 0.011 & -6 & $\mathrm{P}$ & $\mathrm{M}$ \\
\hline 33 & Leather & 167 & 284 & 605 & 0.207 & 0.218 & 0.011 & 5 & P & M \\
\hline 34 & Gold and Uranium Mining & 13348 & 17410 & 19752 & 0.000 & 0.012 & 0.012 & $* *$ & P & $\mathrm{M}$ \\
\hline 35 & Agriculture, Forestry and Fishing & 11197 & 24700 & 27730 & 0.052 & 0.064 & 0.012 & 24 & P & P \\
\hline 36 & Food & 4642 & 13802 & 16472 & 0.027 & 0.064 & 0.037 & 140 & $\mathrm{P}$ & $\mathrm{P}$ \\
\hline 37 & Textiles & 1652 & 3317 & 3555 & 0.093 & 0.136 & 0.043 & 46 & $\mathrm{P}$ & P \\
\hline 38 & Tobacco & 292 & 951 & 1117 & 0.035 & 0.124 & 0.089 & 254 & P & $\mathrm{P}$ \\
\hline 39 & Water supply [42] & 1064 & 3628 & 3598 & & & & & & \\
\hline 40 & $\begin{array}{l}\text { Excluding medical, dental and } \\
\text { veterinary services [94-96] }\end{array}$ & 1682 & 7929 & 10107 & & & & & & \\
\hline 41 & $\begin{array}{l}\text { Catering and accommodation services } \\
{[64]}\end{array}$ & 2190 & 7913 & 8407 & & & & & & \\
\hline 42 & $\begin{array}{l}\text { Civil engineering and other construction } \\
{[52-53]}\end{array}$ & 2869 & 9660 & 11479 & & & & & & \\
\hline 43 & Communication [75] & 3788 & 21488 & 37429 & & & & & & \\
\hline 44 & Other producers [98] & 6317 & 20519 & 27200 & & & & & & \\
\hline 45 & Business services [83-88] & 13969 & 74553 & 106254 & & & & & & \\
\hline 46 & General government services $[90]$ & 25571 & 120342 & 145270 & & & & & & \\
\hline & Contribution to GDP of 38 sectors: $\mathrm{L}$ & & & & & & & & $23 ; 23 ; 22$ & $30 ; 30 ; 30$ \\
\hline & (FV study) M & & & & & & & & $43 ; 46 ; 45$ & $53 ; 55 ; 56$ \\
\hline 49 & $\mathrm{P}$ & & & & & & & & $34 ; 30 ; 33$ & $17 ; 15 ; 13$ \\
\hline & Contribution to total GDP: L & & & & & & & & $16 ; 14 ; 13$ & $21 ; 18 ; 19$ \\
\hline 51 & $\mathrm{M}$ & & & & & & & & $30 ; 29 ; 28$ & $38 ; 34 ; 34$ \\
\hline 52 & & & & & & & & & $25 ; 19 ; 20$ & $12 ; 9 ; 8$ \\
\hline 53 & & & & & & & & & & \\
\hline
\end{tabular}

Soure: Own calculations with data from Federekke, J and Vaze, P, 2001, Trade and Industrial Policy Strategies Database. Notes: 1 . Change in the average ERP for the period 1988-93 and 1994-98.

2. Percentage change in the average EPR between the period 1988-93 and 1994-98 
Table 5. Extent of trade liberalisation (ERP calculations based on statutory rates)

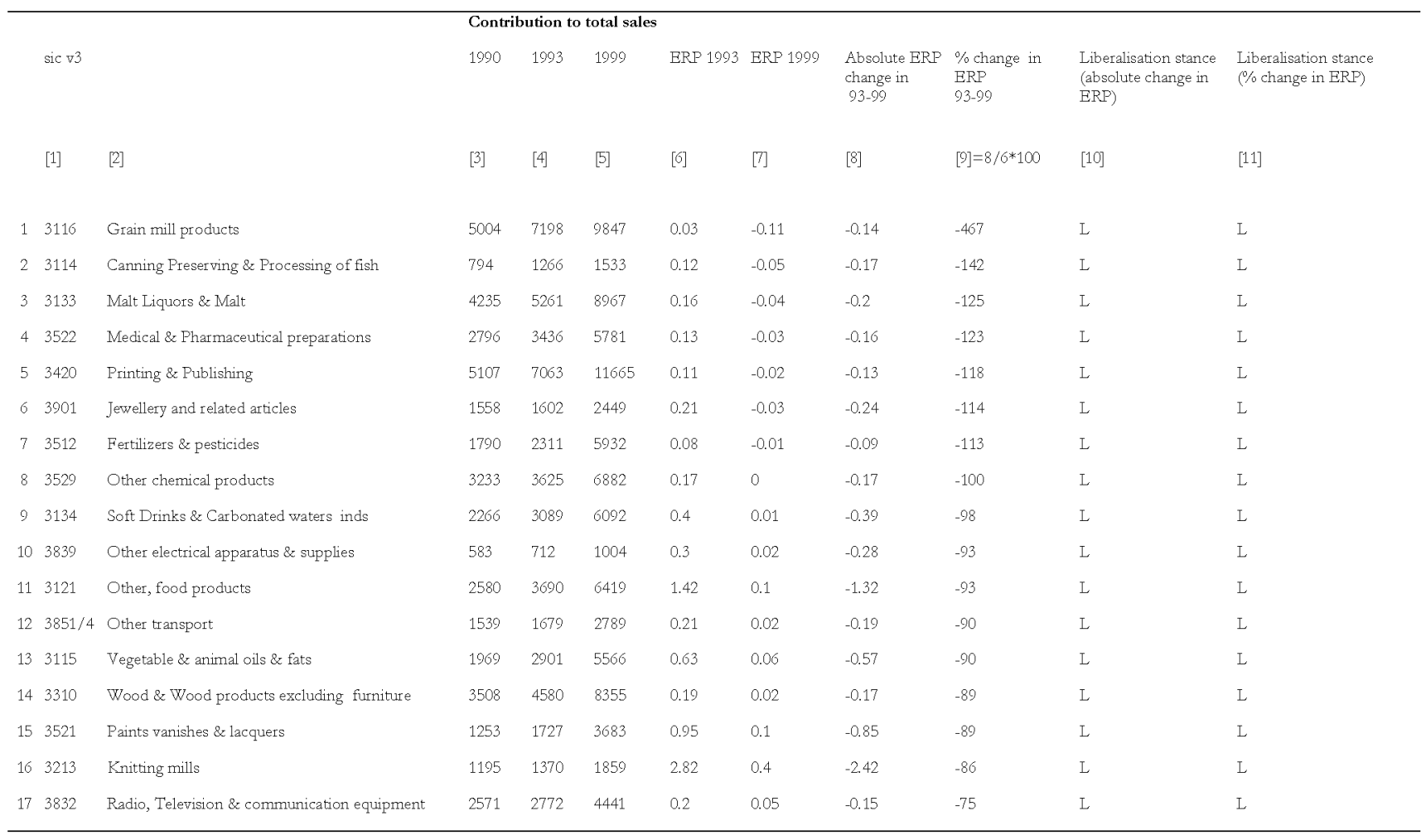




\begin{tabular}{|c|c|c|c|c|c|c|c|c|c|c|c|}
\hline 18 & 3831 & Electrical industrial machinery & 630 & 808 & 2130 & 0.16 & 0.04 & -0.12 & -75 & I & I \\
\hline 19 & 3710 & Iron \& Steel basic industries & 13362 & 15041 & 26057 & 0.12 & 0.04 & -0.08 & -67 & L & L \\
\hline 20 & 3119 & Cocoa, Chocolate \& Sugar confectionery & 1204 & 1552 & 2911 & 0.34 & 0.13 & -0.21 & -62 & I & L \\
\hline 21 & 3819 & Other fabricated metals excluding machinery & 5963 & 7560 & 11054 & 0.3 & 0.13 & -0.17 & -57 & I & I \\
\hline 22 & 3523 & Soap, cosmetics \& toilet preparations & 2519 & 3824 & 7606 & 1.26 & 0.57 & -0.69 & -55 & I & L \\
\hline 23 & 3220 & Wearing apparel excluding footwear & 4848 & 5837 & 9136 & 3.54 & 1.62 & -1.92 & -54 & I & L \\
\hline 24 & 3211 & Spinning, Wool weaving \& finishing of fabrics & 3907 & 4586 & 6305 & 1.23 & 0.6 & -0.63 & -51 & I & I \\
\hline 25 & 3412 & Paper containers & 2970 & 3720 & 6814 & 0.5 & 0.28 & -0.22 & -44 & I & L \\
\hline 26 & 3620 & Glass \& Glass products & 1612 & 1606 & 2141 & 0.16 & 0.09 & -0.07 & -44 & I & I \\
\hline 27 & 3551 & Tyres \& Tubes & 875 & 826 & 972 & 0.48 & 0.31 & -0.17 & -35 & I & L \\
\hline 28 & 3559 & Other rubber products & 1744 & 2077 & 3195 & 0.2 & 0.13 & -0.07 & -35 & I & I \\
\hline 29 & 3240 & Footwear & 1807 & 2131 & 2379 & 0.75 & 0.49 & -0.26 & -35 & I & L \\
\hline 30 & 3560 & Other plastic products & 4328 & 5810 & 9723 & 0.48 & 0.34 & -0.14 & -29 & I & L \\
\hline 31 & 3811 & Cutlery, Hand tools \& General hardware & 975 & 1115 & 1839 & 0.31 & 0.27 & -0.04 & -13 & L & L \\
\hline 32 & 3111 & Slaughtering Preparing \& Freserving Meat & 2653 & 3349 & 5693 & 5.13 & 4.49 & -0.64 & -12 & I & I \\
\hline 33 & 3419 & Other Pulp, paper \& paperboard & 1185 & 1880 & 3567 & 0.27 & 0.25 & -0.02 & -7 & I & $\mathrm{M}$ \\
\hline 34 & $3843 / 0$ & Motor vehicles & 15497 & 20883 & 42720 & 1.21 & 1.13 & -0.08 & -7 & I & $\mathrm{M}$ \\
\hline 35 & 3833 & Electrical appliances \& house wares & 1205 & 1358 & 1926 & 0.56 & 0.56 & 0 & 0 & $\mathrm{M}$ & $\mathrm{M}$ \\
\hline 36 & 3411 & Pulp, Faper \& Paperboard & 4361 & 4909 & 10019 & 0.08 & 0.08 & 0 & 0 & $\mathrm{M}$ & $\mathrm{M}$ \\
\hline 37 & 3691 & Bricks, Tiles, re-factories, etc. & 1466 & 1594 & 2431 & 0.17 & 0.17 & 0 & 0 & $\mathrm{M}$ & $\mathrm{M}$ \\
\hline 38 & 3692 & Cement & 1224 & 1632 & 2313 & -0.02 & -0.02 & 0 & 0 & $\mathrm{M}$ & $\mathrm{M}$ \\
\hline 39 & 3511 & Industrial chemicals & 712 & 793 & 1391 & 0 & 0 & 0 & 0 & $\mathrm{M}$ & $\mathrm{M}$ \\
\hline 40 & 3610 & Pottery, China \& Earthenware & 226 & 230 & 270 & 0.32 & 0.33 & 0.01 & 3 & $\mathrm{P}$ & $\mathrm{M}$ \\
\hline 41 & 3320 & Furniture & 3028 & 3451 & 6356 & 0.5 & 0.53 & 0.03 & 6 & $\mathrm{P}$ & $\mathrm{M}$ \\
\hline
\end{tabular}




\begin{tabular}{|c|c|c|c|c|c|c|c|c|c|c|c|}
\hline 42 & 3212 & Ma.de-up textile goods, exc wearing apparel & 992 & 1257 & 1659 & 0.77 & 0.82 & 0.05 & 6 & $\mathrm{P}$ & $\mathrm{M}$ \\
\hline 43 & 3219 & Textiles, not elsewhere classified & 423 & 614 & 1105 & 0.15 & 0.2 & 0.05 & 33 & $\mathrm{P}$ & $\mathrm{P}$ \\
\hline 44 & 3233 & Leather products \& leather substitutes & 871 & 1065 & 2578 & 0.57 & 0.81 & 0.24 & 42 & $\mathrm{P}$ & $\mathrm{P}$ \\
\hline 45 & 3214 & Carpets \& rugs mats \& matting & 459 & 610 & 701 & 0.6 & 0.86 & 0.26 & 43 & $\mathrm{P}$ & $\mathrm{P}$ \\
\hline 46 & 3113 & Canning \& preserving of fruit \& vegetables & 2180 & 2720 & 4489 & 0.32 & 0.49 & 0.17 & 53 & $\mathrm{~F}$ & $\mathrm{~F}$ \\
\hline 47 & 3117 & Bakery products & 2598 & 3577 & 4157 & 0.85 & 1.62 & 0.77 & 91 & $\mathrm{P}$ & $\mathrm{P}$ \\
\hline 48 & 3131 & Distilleries \& wineries & 2699 & 3226 & 5546 & 0.44 & 1.85 & 1.41 & 320 & $\mathrm{~F}$ & $\mathrm{P}$ \\
\hline 49 & 3122 & Prepared animal feeds & 2380 & 2987 & 5025 & -0.2 & 1.19 & 1.39 & 695 & P & P \\
\hline 50 & 3112 & Diary Products & 3227 & 4601 & 7165 & 0.16 & 1.84 & 1.68 & 1050 & P & $\mathrm{P}$ \\
\hline 51 & 3118 & Sugar factories \& refineries & 2124 & 2528 & 4473 & 0.1 & 4.99 & 4.89 & 4890 & $\mathrm{~F}$ & $\mathrm{~F}$ \\
\hline 52 & & Contribution to sales of 51 sectors $\quad \mathrm{L}$ & & & & & & & & $80 ; 81$ & $67 ; 66$ \\
\hline 53 & & $\mathrm{M}$ & & & & & & & & $6 ; 6$ & $21 ; 25$ \\
\hline 54 & & P & & & & & & & & $13 ; 13$ & $11 ; 10$ \\
\hline 55 & & Contribution to manufacturing sales $\mathrm{L}$ & & & & & & & & $60 ; 61$ & $50 ; 49$ \\
\hline 56 & & $\mathrm{M}$ & & & & & & & & $5 ; 5$ & $16 ; 18$ \\
\hline 57 & & $\mathrm{P}$ & & & & & & & & $10 ; 10$ & $8 ; 8$ \\
\hline
\end{tabular}

Source: IDC, 1996; Trade and Industrial Policy Strattgies Database, own calculations 


\section{REFERENCES}

ANDERSON, J. (1998). Effective Protection Redux, Journal ofInternational'Economics, 44, 21-44.

BELL, T. (1993). Should South Africa Further Liberalise its Foreign Trade? In Lipton, M. and

Simpkms, C. (eds.), State and Market in Post-Apartheid South Africa. Witwatersrand University Press.

(1997). "Trade Policy" in Michie, J. and Padayachee, V (eds), The Political Economy of South Africa's Transition. Dryden Press, London. BELLI, P., FINGER, M. AND BALLIVAN, A.

(1993). South Africa: A Review of Trade Policies.

Discussion Paper, no 4. Washington DC: The World Bank. BHAGWATI, J. AND SRINIVASAN,

T.N. (1973): Lectures on International Trade, MIT, Cambridge MA. CARBAUGH, R.J. (2000). International

Economics, South-Western College Publishing, Ohio. CORDEN, W. M. (1966): "The Structure of a Tariff System and the Effective Protection Rate",

Journal of Political Economy, vol. 74, pp221-237.

__ (1969): "Effective Protection Rates in the General Equilibrium Model: A Geometric Note", Oxford Economic Papers, vol. l, pp 135-141.

(1971): "The substitution problem in the theory of effective protection", Journal of International Economics, vol. 1, pp 37-57. DTI, (2002). Accelerating growth and development: the contribution of an integrated manufacturing sector, Strategy Document, Department of Trade and Industry, Pretoria.

ECKES, A.E. (1995). Opening Am erica's market: U.S. foreign trade policy since 1776. Chapel Hill, University of North Carolina Press, North Carolina. ETHIER, W.J. (1971). "General Equilibrium and the Concept of Effective Protection", in H.G. Grubel and J.J.Johnson (eds), Effective Tariff Protection, GATT, Geneva.

_ (1977): "The Theory of Effective Protection in General Equilibrium: Effective Rate Analogues of Nominal Rates", Canadian Journal of Economics, vol. 10, pp233-245. FALLON, P.

AND PEREIRADE SILVA, L. (1994). South Africa: economic performance and policies, Informal discussion papers on aspects of the SA economy, No. 7, South Africa Department, World Bank, Washington.

(1994). South Africa: Economic Performance and Policies, Informal discussion papers on aspects of the economy of $S$ outh Africa, World Bank, Washington. FEENSTRA, R.C. (1995). Estimating

the effects of trade policy, NBER working paper no 5051, NBER, Cambridge, MA. FEDDERKE,J. AND VAZE, P. (2001). The Nature of South Africa's Trade Patterns by Economic Sector, and the Extent of Trade Eiberalisation During the Course of the 1990's. South African Journal of Economics, 69(4):436-473. FINE, B. AND RUSTOMJEE, Z. (1996). South Africa's Political Economy: From Minerals-Energy-Complex to Industrialisation. Witwatersrand University Press, Johannesburg. GATT. (1993). Trade

Poliy Review Mechanism: The Republic of South Africa, report by the secretariat, C/RM/S/37A, GATT, Geneva. GEAR. (1996). Growth, employment and ^distribution: A macroeconomic strategy. Ministry of Finance, Pretoria GREENAWAY, D. (1983). International Trade Poliy: From tariffs to the new protectionism. MacMillan Press, London. and Milner, C. (2002): "Effective Protection Policy Appraisal and Trade Policy Reform", paper presented at the "Trade, exchange rate regimes and growth: a conference in honour of Max Corden", School of advanced international studies, John Hopkins University, Washing DC, 19 April 2002. HOLD EN, M. (1999). The structure and incidence of protection in South Africa, Paper presented at the 1999 conference of the Economic Society of South Africa. (2001). Effective Protection revisited: Mow useful a poliy tool for South Africa? South African Journal of Economics, 69(4):659-673.. (2001). Trade Poliy in a Liberalising Economy, mimeo, University of Natal, Durban. 
IndUSTRIAL DeVELOPMENT Corporation. (1990). Modification of the Application of Protection Policy. IDC, Sandton.

(1996). The tariff rationalisation process, presentation to Portfolia Committee on Trade and Industry, 30 September, IDC, Sandton. INTERNATIONAL MONETARY FUND. (2000). South Africa: selected issues. IMF Staff Country Report

no. 00/42:51-58. JONES, R.W. (1971) "Effective Protection and Substitution", Journal

ofInternational Economics, vol. 1,

Pp 59-82. KUHN, G. AND JANSEN, R. (1996). The effective protection rate and anti export bias. IDC, Sandton. LERNER, A.P. (1936). The symmetry between import and export taxes, Economica, 3:306313. MCCARTHY, C. (1999). The Manufacturing Sector during the 1970s. South African Journal of Economic

History, 14(September):143-161. O'ROUKE, K. (2000). Tariffs and growth in the late nineteenth Century. Economic Journal, 110(463):

456-483. REPUBLIC OF SOUTH AFRICA, (1993). Trade Policy Review Mechanism: The Republic of South Africa.

Report by the Government, C/RM/G/37, GATT, Geneva. STRYDOM, P.D.F. (1995). International Trade and Economic Growth- The Opening-up of the South African Economy. South African Journal of Economics, 63(4):556-569. TRADE AND INDUSTRY POLICY STRATEGY (TIPS). 2002. The state of trade policy in South Africa,

Johannesburg. VAN SEVENTER, D. (2001). The level and variation of tariff rates: an analysis of tariff rates in South Africa.

Trade and Industry Monitor, September 2001, Tips, Johannesburg, 5-9. WTO. (1999).

Trade Policy Review, Republic of South Africa. WT/TPR/S/34, World Trade

Organisation, Geneva. 